\title{
Kinerja pegawai dengan dukungan kecerdasan Emosional dan kepuasan kerja
}

(Studi Empirik: Diskoperindag Kabupaten Pemalang)

\section{Heru Eko Prasetyo.SE.MM}

heruekoprasetyountag@gmail.com

\begin{abstract}
Abstrak Sumber daya manusia yang professional sangat dibutuhkan dalam suatu organisasi untuk mencapai tujuan. .Profesional akan nampak dari kinerja karyawan yang dipengaruhi faktor kecerdasan emosional dan kepuasan kerja karyawan. Demikian juga pada Kantor Diskoperindag Kabupaten Pemalang, masalah yang nampak kuantitas pegawai kurang dalam penyelesaian pekerjaan, masih rendahnya kualitas kerja yang dihasilkan pegawai ,rendahnya produktivitas organisasi inovasi yang terhambat, dan semangat kerja menurun.Metode penelitian dengan metode sensus dan analisis data dengan Regresi Linear Berganda.Populasi dan sampel adalah seluruh karyawan/ pegawai Diskoperindag Kabupaten Pemalang sebanyak 119 pegawai berstatus pegawai tetap (ASN).Tujuan penelitian ini untuk mengetahui pengaruh kecerdasan emosional dan kepuasan kerja terhadap kinerja pegawai. Hasil penelitian menunjukan bahawa kecerdasan emosional berpengaruh positif dan signifikan terhadap Kinerja pegawai pada Kantor Diskoperindag Kabupaten Pemalang dan kepuasan kerja berpengaruh positif dan signifikan terhadap Kinerja pegawai pada Kantor Diskoperindag Kabupaten Pemalang.
\end{abstract}

Kata Kunci Kinerja Pegawai, Kecerdasan emosional dan Kepuasan kerja

\section{PENDAHULUAN}

Sumber daya manusia merupakan kunci keberhasilan suatu organisasi untuk mencapai tujuan yang diinginkan maka perlu dikelola secara professional, hal ini mengarah kepada kinerja pegawai.. Dalam rangka melihat kinerja pegawai maka yang harus diperhatikan antara lain kecerdasan emosional dan kepuasan kerja karyawan.Menurut Hasibuan (2003), kinerja adalah hasil kerja yang dicapai seseorang dalam melaksanakan tugas-tugasnya atas kecakapan, usaha, dan kesungguhan serta waktu yang sesuai dengan standar dan kriteria. Sedangkan, menurut Salovey dan Mayer (1990) mendefinisikan kecerdasan emosional sebagai kemampuan untuk memantau dan membedakan perasaan dan emosi seseorang maupun orang lain, dimana informasi tersebut digunakan untuk membimbing pemikiran dan tindakan seseorang. Sementara itu, menurut Dole and Schroeder (2001), kepuasan kerja didefinisikan sebagai reaksi dan perasaan seseorang terhadap tempat ia bekerja.Ahli lain mendefinisikan kepuasan kerja merupakan respons emosional dan efektivitas yang berdampak pada aspek pekerjaan.. Adanya peningkatan kepuasan kerja pada karyawan tentu berdampak pada kinerja yang ditunjukkannya.

Pada Dinas Koperasi Perdagangan dan Perindustrian (Diskoperindag) Kabupaten Pemalang, penilaian kinerja pegawai menggunakan indikator Sasaran Kerja Pegawai (SKP)/ Prestasi kerja, dan penilaian Perilaku Kerja dengan indikator Orientasi Pelayanan, 
Integritas, Komitmen, Disiplin, Kerjasama, dan Kepemimpinan. Penilaian kinerja ini dilakukan satu tahun sekali yaitu pada bulan desember dan dinilai oleh pejabat penilai yakni atasan langsung pegawai tersebut.

Berdasarkan rekapitulasi rata-rata hasil penilaian kinerja pegawai tahun 2019 dan 2020 menunjukkan kinerja cukup baik pada tahun 2019 dan pada tahun 2020 mengalami penurunan sebesar 10,14\% dari tahun 2019 pada unsur Sasaran Kerja Pegawai (SKP), Orientasi Pelayanan, Integritas, Komitmen, Disiplin dan Kerjasama yang cukup signifikan.

Fenomena yang ada kuantitas pegawai kurang dalam penyelesaian pekerjaan , masih rendahnya kualitas kerja yang dihasilkan pegawai ,rendahnya produktivitas organisasi inovasi yang terhambat, dan semangat kerja menurun.Oleh karena itu, jika hal tersebut tidak bisa diatasi Diskoperindag maka dapat menurunkan kinerja pegawai.Sehingga dinas harus dapat meningkatkan kinerja pegawainya dengan melakukan pembenahan pegawai dilihat dari kecerdasan emosional dan kepuasan kerja para pegawainya.

Penelitian mengenai pengaruh keceedasan emosional dan kepuasan kerja terhadap kinerja karyawan sudah pernah dilakukan oleh peneliti-peneliti sebelumnya. Dari berbagai penelitian-penelitia tersebut menunjukkan adanya inkonsistensi hasil yang ditunjukkan dari adanya penelitian yang berbeda atau research gab,yang dapat dijadikan dorongan untuk melakukan penelitian ini.Perbedaan hasil penelitian yaitu Wan Dedi Wahyudi (2019) menyatakan bahwa kepuasan kerja berpengaruh positif tetapi tidak signifikan terhadap kinerja pegawai.Rumusan masalah penelitian ini berdasarkan uarian tersebut diatas adalah Bagaimana pengaruh kecerdasan emosional terhadap kinerja pegawai dan Bagaiman pengaruh kepuasan kerja terhadap kinerja pegawai pada Dinas Koperasi Perdagangan dan Perindustrian (Diskoperindag) Kabupaten Pemalang ?

\section{LANDASAN TEORI Kinerja Karyawan}

Kinerja adalah hasil kerja yang dicapai seseorang dalam melaksanakan tugas-tugasnya atas kecakapan, usaha, dan kesungguhan serta waktu yang sesuai dengan standar dan kriteria (Hasibuan ;2003). Sedangkan menurut Rivai dan Basri dalam Sinambela (2012) menyatakan bahwa kinerja merupakan hasil atau tingkat keberhasilan seseorang atau keseluruhan selama periode tertentu di dalam melaksanakan tugas dibandingkan dengan berbagai kemungkinan, seperti standar hasil kerja, target atau sasaran atau kriteria yang telah ditentukan terlebih dahulu dan telah disepakati bersama.Sementara itu, John Miner dalam Sudarmanto (2009) mengemukakan ada 4 dimensi sebagai tolok ukur dalam menilai kinerja: Kualitas, yaitu tingkat kesalahan, kerusakan, kecermatan; Kuantitas, yaitu jumlah pekerjaan yang dihasilkan; Penggunaan waktu dalam kerja, yaitu tingkat ketidakhadiran, keterlambatan, waktu kerja efektif atau jam kerja hilang; dan Kerjasama dengan orang lain dalam bekerja.

\section{Kecerdasan Emosional}

Kecerdasan Emosional sebagai kemampuan untuk memantau dan membedakan perasaan dan emosi seseorang maupun orang lain, dimana informasi tersebut digunakan untuk membimbing pemikiran dan tindakan seseorang.( Salovey dan Mayer (1990).Disisi lain, Goleman (2003) menjelaskan bahwa karyawan dengan kecerdasan emosional yang lebih tinggi akan lebih terampil dalam memfasilitasi kinerja pekerjaan mereka, dan menyadari pengaruh emosi terhadap perilaku dan hasil kinerja mereka. menurut Salovey dalam 
(Goleman, 2015: 56) aspek aspek kecerdasan emosi adalah mengenali emosi diri, mengelola emosi, memotivasi diri sendiri, mengenali emosi oreang lain, dan membina hubungan.

\section{Kepuasan Kerja}

Kepuasan kerja didefinisikan sebagai reaksi dan perasaan seseorang terhadap tempat ia bekerja. (Dole and Schroeder ,2001). Sedangkan Kreitner dan Kinicki (2005) mendefinisikan kepuasan kerja merupakan respons emosional dan efektivitas yang berdampak pada aspek pekerjaan. Dan menurut Asad (2000) menjelaskan bahwa kepuasan kerja adalah suatu sikap umum yang berupa hasil dari beberapa sikap khusus terhadap karakteristik individual, hubungan kelompok di luar pekerjaannya serta faktorfaktor pekerjaan. Menurut Smith, Kendall \& Hulin (Luthans, 2006), dimensi yang dapat mengukur kepuasan kerja, yaitu: Pekerjaan itu sendiri (Work it self), Atasan (Supervisor), Teman sekerja (Workers), Promosi (Promotion), dan Gaji (Pay).

. Dalam penelitian ini hipotesis yang di ajukan adalah sebagai berikut :

1) $\mathrm{H}_{1}$ : Terdapat pengaruh positif dan signifikan kecerdasan emosional terhadap kinerja pegawai pda Kantor Diskoperindag Kabupaten Pemalang.

2) $\mathrm{H}_{2}$ : Terdapat pengaruh positif dan signifikan kepuasan kerja terhadap kinerja pegawai pda Kantor Diskoperindag Kabupaten Pemalang.

\section{METODOLOGI PENELITIAN}

Populasi dalam penelitian ini adalah seluruh karyawan/ pegawai Diskoperindag Kabupaten Pemalang sebanyak 119 pegawai berstatus pegawai tetap (ASN) terdiri dari 49 pegawai yang berada pada kantor Diskoperindag Kabupaten Pemalang dan 70 pegawai yang berada pada pasar di wilayah Kabupaten Pemalang yang tersebar di 14 Kecamatan..Sampel yang digunakan adalah pegawai Diskoperindag Kabupaten Pemalang yang berstatus pegawai tetap (ASN) yang berjumlah 119 orang dengan metode sensus.

Variabel independen dalam penelitian ini terdiri dari (1) Kecerdasan Emosional (X1) adalah kapasitas dalam mengenali perasaan diri sendiri dan orang lain, dalam memotivasi diri sendiri dan mengelola emosi dengan baik dalam diri sendiri maupun dalam hubungan dengan orang lain. 2) Kepuasan kerja (X2) yaitu keadaan emosional yang menyenangkan atau tidak menyenangkan para karyawan dalam bekerja dan memandang pekerjaannya.Sedangkan variabel dependennya adalah kinerja pegawai (Y), yaitu catatan yang dihasilkan dari fungsi suatu pekerjaan tertentu atau kegiatan selama periode waktu tertentu.

Sumber data yang digunakan adalah data primer yaitu data yang diperoleh langsung dari sumber data dengan cara mengadakan penelitian langsung ke lapangan, dengan cara menyebar kuesioner ke seleuruh pegawai. Sumber data yang juga dipakai adalah Studi Pustaka yaitu dengan cara menelaah bahan bahan seperti buku -buku yang memuat teoriteori, karya ilmiah dan bahan lain yang relevan dalam penelitian.Teknis analisis Data yang digaunakan adalah Analisis Regresi Linier Berganda persamaannya $: \hat{Y}=a+\beta_{1} X_{1}$ $+\beta_{2} X_{2}+e$

Keterangan :

$\hat{Y}=$ Variabel Terikat (Kinerja pegawai)

$\mathrm{a}=$ Konstanta

$\beta_{1}$ dan $\beta_{2}=$ Parameter Koefisien Regresi

$\mathrm{X} 1=$ Variabel bebas pertama (Kecerdasan emosional) 
$\mathrm{X} 2$ = Variabel bebas kedua (Kepuasan kerja)

\section{HASIL PENELITIAN}

Hasil analisis Regresi linear Berganda pengaruh Kecerdasan Emosional dan Kepuasan Kerja terhadap Kinerja Pegawai diperoleh persamaan linier berganda sebagai berikut ini $: \mathbf{Y}=17,573+0,494 \mathbf{X}_{1}+0,275 \mathbf{X}_{2}+\mathrm{e}$

\section{Pengaruh Kecerdasan emosional terhadap Kinerja pegawai}

Berdasarkan hasil yang diperoleh pada table diatas, nilai t hitung variable kecerdasan emosional sebesar 6,48, dan nilai tersebut lebih besar daripada nilai t tabel yaitu $(6,487>$ 1,981), serta nilai signifikansi sebesar i 0,025(uji dua sisi), sehingga hasil keputusannya adalah menerima hipotesis alternative (Ha). Artinya bahwa Kecerdasan emosional berpengaruh positif dan signifikan terhadap Kinerja pegawai. Hasil ini menunjukkan jika kecerdasan emosional para pegawai semakin baik dan efektif, maka kinerja pegawai akan semakin meningkat. Sehingga dapat disimpulkan bahwa hipotesis satu yang menyatakan ada pengaruh positif dan signifikan kecerdasan emosional terhadap kinerja pegawai secara statistic dapat diterima.

Hasil tersebut menunjukan bahwa . Kecerdasan emosional yang dimiliki oleh Pegawai Diskoperindag dikelola dengan baik dan efektif menjadi salah satu faktor sangat penting yang akan mampu untuk meningkatkan kinerja pegawai. Hal ini dilihat dari pengaruhnya yang positif dan signifikan, saehingga adanya peningkatan kecerdasan emosional akan berdampak pada peningkatan kinerja pegawai.

Hal ini menunjukkan bahwa semakin baik dan efektif kecerdasan emosional yang diukur dengan Pengenalan diri (Self-awareness); Pengendalian diri (Self-regulation); Motivasi (Motivation); Empati (Emphaty); dan Keterampilan sosial (Social skills) maka kinerja pegawai semakin baik.Hasil ini telah mendukung hasil penelitian dari Irma Mulyasari (2018), dan Triana Fitriastuti, (2013) yang menyatakan kecerdasan emosional berpengaruh positif dan signifikan terhadap kinerja pegawai

\section{Pengaruh Kepuasan kerja terhadap Kinerja pegawai}

Berdasarkan hasil yang diperoleh pada tabel diatas, nilai t hitung 1 variabel Kepuasan kerja sebesar 3,276, dan nilai tersebut lebih besar daripada nilai t tabel yaitu (3,276 > 1,981) serta nilai signifikansi 0,025 (uji 2 sisi), sehingga hasil keputusannya adalah menerima hipotesis alternative (Ha). Artinya bahwa kepuasan kerja berpengaruh positif dan signifikan terhadap Kinerja pegawai.

Hasil ini menunjukkan jika semakin tinggi kepuasan kerja maka kinerja pegawai akan semakin meningkat.Sehingga dapat disimpulkan bahwa hipotesis dua yang menyatakan bahwa ada pengaruh positif dan signifikan kepuasan kerja terhadap kinerja pegawai secara statistic dapat diterima.

Hasil tersebut menunjukkan bahwa kepuasan kerja yang dimiliki pegawai Pegawai Diskoperindag Kabupaten Pemalang sangat tinggi menjadi salah satu faktor yang sangat penting yang akan mampu untuk meningkatkan kinerja pegawai.Hal ini menunjukkan bahwa semakin tinggi kepuasan kerja yang diukur dengan Pekerjaan itu sendiri (Work It Self), Atasan (Supervision), Rekan kerja (Co-workers), Kesempatan promosi (Promotion opportunities), dan Gaji/ upah (Pay), maka kinerja pegawai semakin meningkat.Hasil ini telah mendukung hasil penelitian dari Ayu Desi Indrawati, (2013), dan Putu Yudha Asteria Putri, (2013) .Hal ini sependapat dengan teori Robbins (2008), yang menyatakan bahwa kepuasan kerja adalah suatu perasaan positif tentang pekerjaan seseorang yang 
merupakan hasil dari evaluasi karakteristiknya. Seseorang dengan tingkat kepuasan yang tinggi menunjukkan sikap yang positif terhadap pekerjaannya dan sebaliknya seseorang yang tidak puas dengan pekerjaannya akan menunjukkan sikap yang negatif terhadap pekerjaannya..

\section{KESIMPULAN DAN SARAN}

Berdasarkan hasil analisis dan pembahasan bahwa Kecerdasan emosional berpengaruh positif dan signifikan terhadap Kinerja pegawai pada Kantor Diskoperindag Kabupaten Pemalang. Demikian juga Kepuasan kerja berpengaruh positif dan signifikan terhadap Kinerja pegawai pada Kantor Diskoperindag Kabupaten Pemalang..

Adapun saran yang dapat direkomendasikan untuk meningkatkan kinerja karyawan adalah mempertahankan dan terus meningkatkan kecerdasan emosional dengan cara memberikan mentoring dan pelatihan kepada karyawan tentang pentingnya kecerdasan emosional. Dalam hali ini, kecerdasan emosional berkaitan dengan mengelola emosi dalam diri dan dalam hubungan dengan orang lain, pelatihan dan mentoring kecerdasan emosional bisa berupa pelatihan berkelompok secara periodik seperti character building. Hal tersebut bisa dilakukan melalui permainan, outbound, atau kegiatan sejenis yang akan melibatkan emosi karyawan, memahami karakter orang lain, dan memupuk semangat kerja sama antar sesama karyawan.

\section{DAFTAR PUSTAKA}

Arikunto, Suharsimi. 2013. Prosedur Penelitian Suwatu Pendekatan Praktik. Jakarta: Rineka cipta.

As'ad, M. 2000. Psikologi Industri . Seri Sumber Daya Manusia. Yogyakarta: Liberty.

Ayu Desi Indrawati, 2013, Pengaruh Kepuasan Kerja terhadap Kinerja Karyawan dan Kepuasan Ppelanggan pada Rumah Sakit Swasta di Kota Denpasar. Jurnal Manajemen, Strategi Bisnis, dan Kewirausahaan Vol. 7, No. 2, Agustus 2013, hal. 135-142.

Bohlander, George, and Snell, Scott. 2010. Principles of Human Resource. Management, 15th ed. Mason, OH: South Western-Cengage Learning.

Cooper, R.K. \& Sawaf, A. 2002. Executive EQ : Kecerdasan Emosional Dalam Kepemimpinan dan Organisasi. PT Gramedia Pustaka Utama. Jakarta.

Cherniss, C. D. G. 2001. The Emotionally Intelligent Workplace How to Select for, Measure, and Improve Emotional Intelligence in Individuals, Groups, and Organizations. San Francisco: Jossey-Bass.

Dole, Carol and Schroeder, Richard G.,2001, The Impact of Varios Factors on the Personality, Job Satisfaction and Turn Over Intention of Profesional Accountants, Managerial Auditing Journal, Vol. 16 No.4 pp 234-245.

Goleman, Daniel. 2009. Working With Emotional Intelligence, terjemahan. Alex Tri Kantjono Widodo Jakarta: PT. Gramedia Pustaka Utama.

2014. Pengaruh budaya organisasi perusahaan dan motivasi terhadap kinerja karyawan pada PT. Perusahaan Gas Negara (Persero) Tbk Medan. Jurnal Ilmiah Manajemen dan Bisnis, 14 (2), 176-184.

2015. Emotional Intelligence : Kecerdasan emosional mengapa EI lebih penting daripada IQ, Jakarta: PT. Gramedia Pustaka Utama

Ghozali, Imam, 2013, Analisis Multivariate dengan Program SPSS, Semarang; Badan Penerbit Universitas Diponegoro.Semarang. 
Handoko, T. Hani. 2001. Manajemen Personalia dan Sumberdaya Manusia. Yogyakarta : BPFE.

Yogyakarta

2008. Manajemen Personalia dan Sumber Daya Manusia. Liberty:

Hasibuan, Malayu S.P. 2003. Manajemen Sumber Daya Manusia. Edisi Revisi. Jakarta : Bumi Aksara.

Aksara.

Irma Mulyasari, 2018, Pengaruh Kecerdasan Emosional dan Kompetensi terhadap Kinerja Pegawai. Journal of management review, Vol. 2, No. 2. hal 190-197.

Kaswan. 2012. Manajemen Sumber Daya Manusia untuk Keunggulan Bersaing Organisasi. Edisi Pertama. Yogyakarta : Graha Ilmu

Kreitner, Robert dan Angelo Kinicki. (2005). Perilaku Organisasi. Jakarta: Salemba Empat.

Lusiawati. 2013. Kecerdasan Emosi dan Penyesuaian Diri pada Remaja Awal yang Tinggal di Panti Asuhan Uswatun Hasanah Samarinda: Ejournal Psikologi, Vol. 1 No. 1, hal. 167-176.

Luthans, Fred. 2006. Perilaku Organisasi. Edisi Sepuluh, PT. Andi: Yogyakarta.

Mangkunegara, Anwar Prabu, 2009. Manajemen sumber daya manusia. Remaja Rosdakarya. Bandung.

Mathis Robert L. 2002. Manajemen Sumber Daya Manusia. Salemba: Jakarta

Mayer \& Salovey. 1990. Emotional Intelligence, (p.185-202). Baywood Publishing Co., Inc.

Mathis, Robert L. dan Jhon H. Jackson. 2006. Manajemen Sumber Daya Manusia. Buku I. Jakarta: Salemba Empat.

Putu Yudha Asteria Putri, 2013, Pengaruh Kepuasan Kerja terhadap Kinerja Karyawan Sektor Piblik, dengan In-Role Performance dan Innovative Performance sebagai Variabel Mediasi. E-Jurnal Akuntansi Universitas Udayana. Vol. 5. No. 3, Th. 2013, hal. 627-638.

Rivai, Veithzal. 2004. Manajemen Sumber Daya Manusia Untuk Perusahaan. Jakarta: Grafindo.

Persada.

2014. Kepemimpinan dan Perilaku Organisasi. Jakarta : Raja Grafindo

Rivai, Veithzal dan Basri. 2005. Performence Appraisal: Sistem yang Tepat untuk Menilai Kinerja Karyawan dan Meningkatkan Daya Saing Perusahaan. Jakarta: Raja Gravindo Persada.

Robbins, P. Stephen dan Judge, Timothy A. 2007. Perilaku Organisasi. Jakarta: Salemba Empat.

-----------. 2008. Perilaku Organisasi. Buku 1. Jakarta: Salemba Empat.

2009. Perilaku Organisasi. Jakarta : Salemba Empat.

Sugiyono. 2010. Metode Penelitian Kuantitatif Kualitatif dan R\&D. Bandung: Alfabeta.

Sutrisno. (2010).Manajemen Sumber Daya Manusia. Jakarta : Kencana Prenada Media Group.

Sudarmanto. 2009. Kinerja dan Pengembangan Kompetensi SDM. Yogyakarta: Pustaka Pelajar.

Sinambela, Lijan Poltak. 2012. Kinerja Pegawai Teori Pengukuran dan Implikasi, Graha Ilmu, Yogyakarta. 
Spector, Paul E, dkk. 2000. Industrial and Organizational Psychology: Research and Practise; Inc. USA.

Safira Khasna Auliya, 2018, Pengaruh Kecerdasan Emosional dan Budaya Organisasional terhadap Kinerja Karyawan melalui Kepuasan Kerja sebagai Variabel Intervening di PT BCI Asia Cabang Jakarta.

Tridhonanto, 2009, Melejitkan Kecerdasan Emosi (EQ) Buah Hati, Jakarta: PT Elex Media Komputindo.

Triana Fitriastuti, 2013, Pengaruh Kecerdasan Emosional, Komitmen Organisasional dan Organizational Citizenship Behavior terhadap Kinerja Karyawan. Jurnal Dinamika Manajemen (JDM). Vol. 4, No. 2, 2013, pp: 103-114.

Wan Dedi Wahyudi, 2019, Pengaruh Budaya Organisasi, Motivasi dan Kepuasan Kerja Terhadap Kinerja Pegawai. Jurnal Ilmiah Magister Manajemen. Vol 2, No. 1, Maret 2019, hal. 31-44.

Wirawan. 2009. Evaluasi Kinerja Sumber Daya Manusia Teori Aplikasi dan Penelitian. Jakarta. Penerbit: Salemba Empat. 